\title{
Analisis Pemahaman Konsep Matematika pada Materi Operasi Bilangan Bulat di SMP Negeri 4 Gorontalo
}

\author{
Novrianus Christian Yanala1 ${ }^{*}$, Hamzah B. Uno ${ }^{2}$, Abas Kaluku ${ }^{3}$
}

\author{
1,2,3 Jurusan Matematika, Fakultas MIPA, Universitas Negeri Gorontalo, \\ Jl. Prof. Dr. Ing. B. J. Habiie, Tilongkabila, Kabupaten Bone Bolango, Gorontalo 96119, Indonesia
}

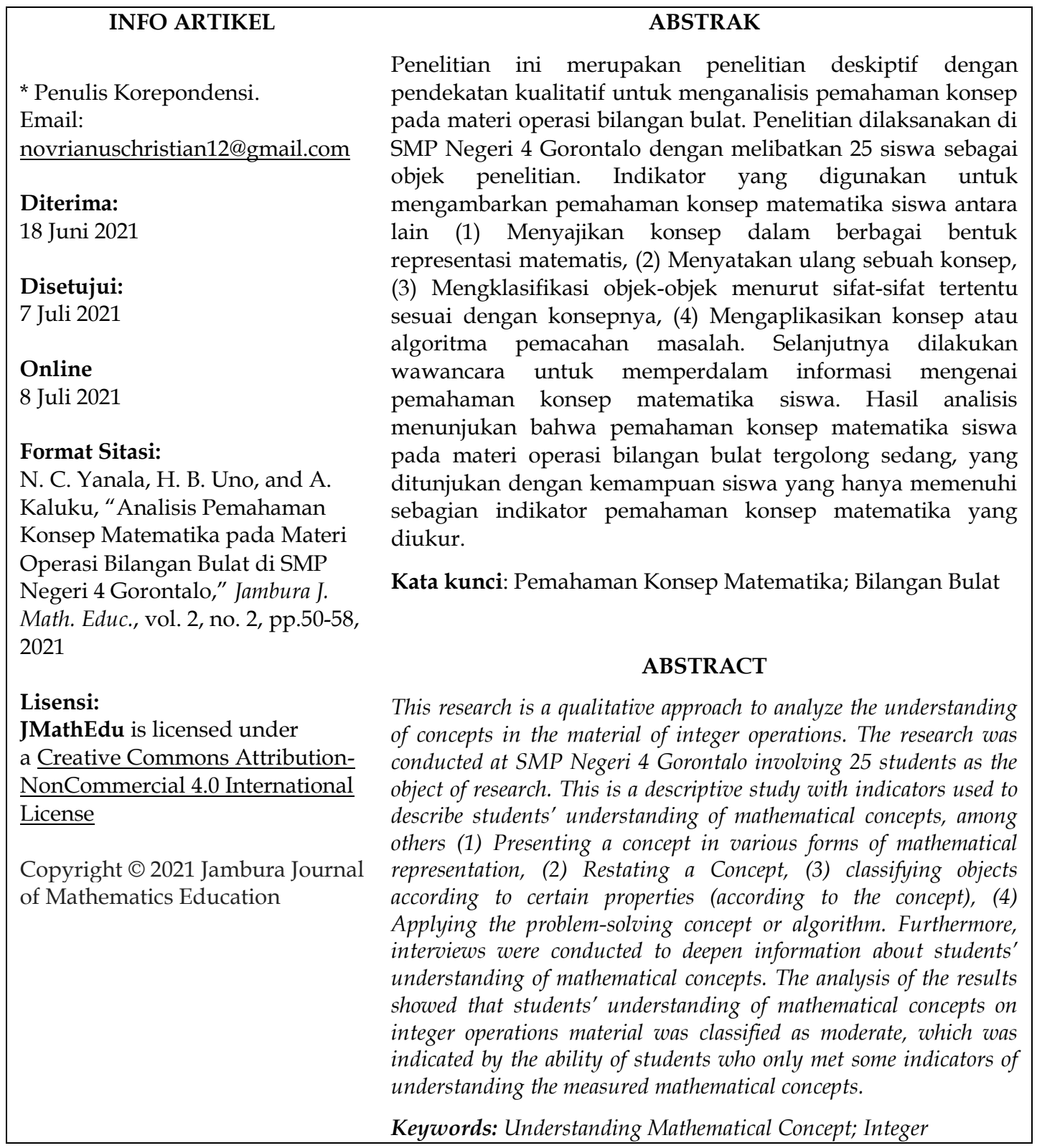

\section{Pendahuluan}

Matematika bukan sekedar berhitung saja akan tetapi merupakan bahasa dan kegiatan untuk memecahkan masalah serta mempelajari pola dan hubungan. Artinya, 
matematika memiliki peranan penting dalam membantu memahami dan menyelesaikan permasalahan dalam kehidupan sehari-hari [1]. Matematika marupakan salah satu ilmu dasar yang mempunyai peran dalam upaya penguasaan ilmu pengetahuan dan teknologi sehinggahnya matematika berkaitan erat dengan kehidupan nyata. Karena itu matematika sangat diperlukan baik dalam kehidupan sehari-hari maupun dalam menghadapi kemajuan IPTEK. Matematika berfungsi untuk mengembangkan kemampuan menghitung, mengukur, menurunkan rumus serta menggunakannya, sehingga dari model matematika dapat dituangkan menjadi suatu kalimat, tabel, diagram, maupun grafik [2]. Tidak hanya itu matematika merupakan ilmu pengetahuan yang kebenarannya objektif, sehingga dalam pelaksanaan pembelajaran matematika siswa sangat dituntut untuk mampu memahami konsepkonsep matematika agar bisa menyelesaikan permasalahan dalam matematika. Hal ini sejalan dengan pendapat Masitoh and Prabawanto [3] yang menyebutkan bahwa pemahaman konsep merupakan dasar dan tahapan penting dalam rangkaian pembelajaran matematika.

Salah satu aspek yang terkandung dalam pembelajaran matematika adalah konsep. Jika diibaratkan konsep merupakan batu-batu dalam berfikir. Akan sangat sulit bagi siswa untuk menuju ke proses pembelajaran yang lebih tinggi jika belum memahami konsep. Pemahaman konsep adalah aspek kunci dari pembelajaran, salah satu tujuan pengajaran yang penting adalah membantu siswa memahami konsep utama dalam suatu objek bukan hanya mangingat fakta-fakta yang terpisah-pisah [4]. Adapun tujuan lain pembelajaran matematika yakni untuk memperoleh kemampuankemampuan dalam menggunakan algoritma, melakukan manipulasi secara matematis, mengorganisasikan data, memanfaatkan symbol, table, grafik, menemukan pola dan konsepnya [5]. Sesuai dengan tujuan pertama pembelajaran matematika diatas maka setelah proses pembelajaran siswa diharapkan dapat memahami suatu konsep matematika sehingga dapat menggunakan kemampuan tersebut dalam menghadapi masalah-masalah matematika. Jadi dapat dikatakan bahwa kemampuan pemahaman konsep kemampuan pemahaman konsep matematika merupakan bagian yang paling pentingdalam pembelajaran matematika. Artinya dalam pembelajaran matematika siswa harus memahami konsep matematika terlebih dahulu agar dapat menyelesaikan soal-soal dan mampu mengaplikasikan pembelajaran tersebut dalam dunia nyata.

Pemahaman konsep yang tidak mantap akan mengakibatkan siswa mengalami kesulitan dalam menyelesaikan soal-soal. Siswa diduga masih kesulitan dalam menentukan rumus mana yang akan dipakai dalam menyelesaikan soal jika hanya mengandalakan hapalan rumus saja tanpa memahami konsep. Hal ini sering terjadi dihampir sebagian besar pokok pembahasan matematika, yang salah satunya adalah pokok pembahsan bilangan bulat. Bilangan bulat adalah salah satu materi yang diberikan di tingkat SMP yang membahas tentang operasi bilangan bulat. Bilangan bulat adalah merupakan suatu bilangan tak pecahan yang terdiri atas bilangan bulat positif, bilangan nol dan bilangan bulat negatif, sedangakan dilihat dari operasinya, operasi bilangan bulat terdiri dari operasi penjumlahan, operasi pengurangan, operasi perkalian dan operasi pembagian. Topik ini yang termaksud salah satu topik yang banyak memunculkan kesulitan bagi siswa disetian satuan pendidikan, termaksud di SMP Negeri 4 Gorontalo. Pemahaman konsep dalam menyelesaikan sola-soal operasi bilangan bulat termaksud yang tidak maksimal disekolah ini. 
Upaya-upaya pengkajian terkait topik pemahaman konsep maupun bilangan bulat dilakukan dari waktu ke waktu, dengan berbagai metode atau pendekatan. Beberepa upaya perbaikan pemahaman konsep matematika dilakukan melalui pendekatan realistik [6][7], pendekatan realistik dengan bantuan alat peraga [8], termasuk upaya perbaikan pemahaman konsep dengan menggunakan bahan ajar [9][10]. Sementara itu, pemahaman konsep pada berbagai topik berbeda juga terus diupayakan, seperti kajian tentang pemahaman konsep aljabar [11], pemahaman konsep bangun ruang sisi lengkung [12], dan pemahaman konsep pada barisan dan deret [13]. Adapun kajian terkait bilangan bulat juga banyak dilakukan, diantaranya pengembangan media untuk oprasi bilangan bulat [14], termasuk upaya untuk meningkatkan pemahaman bilangan bulat melalui Metode Problem Solving [15]. Banyaknya kajian terkait topik ini dari berbagai sudut pandang dengan hasil yang juga beragam menunjukkan bahwa topik ini terus terbuka untuk dilakukan kajian. Pada penelitian ini, dilakukan kajian untuk menggali pemahaman konsep matematika siswa, lebih spesifik pada materi operasi bilangan bulat.

\section{Metode}

Penelitian ini dilaksanakan di SMP Negeri 4 Gorontalo. Penelitian dilaksanakan pada tahun ajaran 2019/2020 disemester ganjil. Metode yang digunakan dalam penelitian ini adalah penelitian deskriptif dengan pendekatan kuantitatif, yaitu penelitian yang dimaksud untuk menyelidiki keadaan, kondisi atau hal lain-lain yng sdah disebutkan, yang hasilnya dipaparkan dalam bentuk lapotan penelitian [16]. Penelitian deskriptif adalah penelitian yang bertujuan untuk m engambarkan fenomena, keadaan, variabel, gejala atau situasi pada saat sekarang. Sumber data dalam penelitian ini adalah kelas VII SMP Negeri 4 Gorontalo tahun ajaran 2019/2020 yang berjumlah 25 siswa.

Variabel merupakan gejala yang bervariasi, yang menjadi objek penelitian. Variabel penelitan adalah objek penelitian atau apa yang menjadi titik perhatian suatu penelitian. Berdasarkan rumusan permasalahan atau definisi, maka dalam penelitian ini hanya ada satu variabel yaitu menyakut pemahaman konsep matematika.

Dalam penelitian ini instrumen atau atau alat bantu yang digunakan adalah instrumen berupa tes dan pedoman wawancara untuk meperdalam informasi mengenai kemampuan pemahan konsep matematika siswa matematika pada materi operasi hitung bilangan bulat. Instrumen tes pemahaman konsep matematika yang diukur berdasarkan indikator (1) menyajikan konsep dalam berbagai bentuk representasi matematis, (2) menyatakan ulang sebuah konsep (3) mengklasifikasi objek-objek menurut sifat-sifat tertentu (sesuai dengan konsepnya, (4) mengaplikasikan konsep atau algoritma pemecahan masalah.

Prosedur pengumpulan data dalam penelitian ini adalah dilakukan melalui dua tahap, yaitu tahap pemberian tes dan tahap wawancara

\subsection{Pemberian tes}

Pemberian tes ini dilakukan untuk mendapatkan informasi yang berkaitan dengan kemampuan awal matematika siswa. Pemberian tes sebagai alat bantu untuk mengumpulkan data tentang hasil belajar matematika kelas VII di SMP 4 Gorontalo pada materi operasi bilangan bulat. Tes merupakan penilaian yang dimaksud untuk mengukur pengetahuan, kemampuan atau bakat yang dimiliki individu atau kelompok. Untuk itu dalam penelitian ini peneliti menggunakan tes untuk mengukur 
pemahaman konsep matematika siswa dalam menyelesaikan soal pada materi operasi bilangan bulat. Oleh kerena itu kegiatan awal dipersiapkan seperangkat tes dalam bentuk essay sebanyak 8 butir soal yang memenuhi indicator pemahaman konsep matematika pada materi operasi bilangan bulat. Pemberian tes ini dilakukan dengan cara online yang dibantu dengan google from.

\subsection{Wawancara}

Wawancara adalah instrumen untuk mengumpulkan data dalam bentuk sejumlah pertanyaan yang diajukan secara lisan. Wawancara terdiri atas pertanyaan-pertanyaan yang akan ditanyakan kepada subjek pada saat melakukan wawancara. Mengingat penelitian ini dilakukan untuk menggambarkan pemahaman konsep matematika siswa dalam menyelesaikan soal yang diberikan, maka wawancara ini untuk melengkapi dan memperkaya informasi mengenai kemampuan pemahaman konsep matematika siswa pada materi operasi bilangan bulat.

Menjelaskan langkah-langkah mengelompokan siswa dalam kemampuan tinggi, sedang dan rendah sebagai berikut.

1) Menjumlah semua nilai matematika.

2) Mencari nilai rata-rata (mean) dan simpangan baku (deviasi standart)

Tabel 2. Kriteria pengelompokan siswa

\begin{tabular}{cc}
\hline Skor $(S)$ & Kelompok \\
\hline$S \geq(\bar{x}+D S)$ & Tinggi \\
$(\bar{x}-S D)<S<(\bar{x}+S D)$ & Sedang \\
$S \leq(\bar{x}-S D)$ & Rendah \\
\hline
\end{tabular}

Sumber: [17]

Keterangan:

$\mathrm{S}=$ Skor siswa,

$\bar{x}=$ Rata-rata skor siswa,

$S D=$ Standar Deviasi

Dalam hal ini, kelompok tinggi adalah siswa yang memiliki skor lebih atau sama dengan skor rata-rata ditambah deviasi standart ke atas, kelompok sedang adalah siswa yang memiliki skor antara skor rata-rata dikurangi deviasi standard dan skor rata- rata ditambah deviasi standar, sementara, kelompok rendah adalah siswa yang memiliki skor kurang dari atau sama dengan skor rata-rata dikurangi deviasi standar kebawah.

\section{Hasil dan Pembahasan}

\subsection{Hasil}

Adapun data hasil penelitian pemahaman konsep matematika pada operasi bilangan bulat berdasrkan hasil penilaian jawaban siswa disajikan pada Table 3. Dari Tabel 3 terlihat bahwa siswa yang termasuk dalam kategori tinggi berjumlah 4 orang dengan persentasi 16\%. Siswa yang termasuk dalam kategori sedang berjumlah 19 orang dengan persentasi $76 \%$. Siswa yang termasuk dalam kategori rendah berjumlah 3 orang dengan persentasi 12\%. Dapat dikatakan bahwa pemahaman konsep matematika pada materi operasi hitung bilangan bulat dikelas VII SMP Negeri 4 Gorontalo tergolong dalam kategori sedang dengan persentasi 76\% dari 19 siswa. 
N. C. Yanala, dkk | Analisis Pemahaman Konsep matematika ...

Tabel 3. Pemahaman konsep matematika

\begin{tabular}{ccc}
\hline Predikat & Jumlah & Presentasi (\%) \\
\hline Tinggi & 3 & $24 \%$ \\
Sedang & 19 & $56 \%$ \\
Rendah & 3 & $20 \%$ \\
\hline Jumlah & 25 & $100 \%$ \\
\hline
\end{tabular}

Adapun data hasil penelitian untuk tiap indikator dapat dilihat pada sajian data berikut.

\subsubsection{Menyajikan konsep dalam berbagai bentuk representasi matematis}

Data hasil perhitungan indikator Menyajikan konsep dalam berbagai bentuk representasi matematis dalam penelitian ini dapat dilihat pada Table 4.

Tabel 4. Menyajikan konsep dalam berbagai bentuk representasi matematis

\begin{tabular}{ccc}
\hline Predikat & Jumlah & Presentasi (\%) \\
\hline Tinggi & 6 & $24 \%$ \\
Sedang & 14 & $56 \%$ \\
Rendah & 5 & $20 \%$ \\
\hline Jumlah & 25 & $100 \%$ \\
\hline
\end{tabular}

Berdasarkan Tabel 4 terlihat bahwa pemahaman konsep matematika pada materi operasi bilangan bulat pada indikator menyatakan konsep dalam berbagai bentuk represesentasi matematis yaitu dari 25 siswa yang termasuk dalam kategori tinggi berjumlah 6 orang dengan persentasi sebesar 24\%. Siswa yang termasuk dalam kategori sedang berjumlah 14 orang dengan persentasi 56\%. Siswa yang termasuk dalam kategori rendah berjumlah 5 orang den gan persentasi $20 \%$. Sehingga dari uraian tersebut dapat dikatakan bahwa pemahaman konsep dalam menyatakan konsep dalam bentuk representasi matematis tergolong sedang.

\subsubsection{Menyatakan ulang sebuah konsep}

Data hasil perhitungan indikator menyatakan ulang sebuah konsep dalam penelitian ini dapat dilihat pada Table 5.

Tabel 5. Menyatakan ulang sebuah konsep

\begin{tabular}{ccc}
\hline Predikat & Jumlah & Presentasi (\%) \\
\hline Tinggi & 6 & $24 \%$ \\
Sedang & 16 & $64 \%$ \\
Rendah & 3 & $12 \%$ \\
\hline Jumlah & 25 & $100 \%$ \\
\hline
\end{tabular}

Berdasarkan Tabel 4.3 terlihat bahwa pemahaman konsep matematika pada materi operasi bilangan bulat pada indikator menyatakan ulang sebuah konsep yaitu dari 25 siswa yang termasuk dalam kategori tinggi berjumlah 6 orang dengan persentasi sebesar $24 \%$. Siswa yang termasuk dalam kategori sedang berjumlah 16 orang dengan persentasi $64 \%$. Siswa yang termasuk dalam kategori rendah berjumlah 3 orang 
dengan persentasi $12 \%$. Sehingga dapat dikatakan bahwa pemahaman konsep matematika dalam menyatakan ulang sebuah konsep tergolong sedang.

\subsubsection{Mengklasifikasi objek-objek menurut sifat-sifat tertentu (sesuai dengan konsepnya)}

Data hasil perhitungan indikator Mengklasifikasi objek-objek menurut sifat-sifat tertentu sesuai dengan konsepnya dalam penelitian ini dapat dilihat pada Table 6 .

Tabel 6. Mengklasifikasikan objek-objek menurut sifat-sifat tertentu

\begin{tabular}{ccc}
\hline Predikat & Jumlah & Presentasi (\%) \\
\hline Tinggi & 8 & $32 \%$ \\
Sedang & 11 & $44 \%$ \\
Rendah & 6 & $24 \%$ \\
\hline Jumlah & 25 & $100 \%$ \\
\hline
\end{tabular}

Berdasarkan Tabel 6 terlihat bahwa pemahaman konsep matematika pada materi operasi bilangan bulat pada indikator Mengklasifikasikan objek-objek menurut sifatsifat tertentu (sesuai dengan konsepnya) yaitu dari 25 siswa yang termasuk dalam kategort tinggi berjumlah 8 orang dengan persentasi sebesar $32 \%$. Siswa yang termasuk dalam kategori sedang berjumlah 11 orang dengan persentasi $44 \%$. Siswa ysang termasuk dalam kategori rendah berjumlah 6 orang dengan presentase $24 \%$. sehingga dapat dikatakan bahwa pemahaman konsep matematika dalam mengklasifikasikan objek-objek menurut sifat-sifat tertentu (sesuai dengan konsepnya), tergolobg sedang.

\subsubsection{Mengaplikasikan konsep atau algoritma pemecahan masalah}

Data hasil perhitungan indikator Mengaplikasikan konsep atau algoritma pemecahan masalah dalam penelitian ini dapat dilihat pada Table 7.

Tabel 7. Mengklasifikasikan konsep atau logaritma pemecahan masalah

\begin{tabular}{ccc}
\hline Predikat & Jumlah & Presentasi (\%) \\
\hline Tinggi & 7 & $28 \%$ \\
Sedang & 14 & $56 \%$ \\
Rendah & 4 & $16 \%$ \\
Jumlah & 25 & $100 \%$ \\
\hline
\end{tabular}

Berdasarkan Tabel 7 terlihat bahwa pemahaman konsep matematika pada materi operasi bilangan bulat pada indikator Mengklasifikasikan konsep atau logaritma pemecahan masalah yaitu dari 25 Siswa yang termasuk dalam kategori tinggi berjumlah 7 orang dengan persentasi $28 \%$. Siswa yang termasuk dalam kategori sedang berjumlah 14 orang dengan persentasi $56 \%$. Siswa yang termasuk dalam kategori rendah berjumlah 4 orang dengan persentasi 16\%. Sehingga dapat dikatakan bahwa pemahaman konsep matematika dalam mengklasifikasikan konsep atau logaritma pemecahan masalah tergolong sedang. 


\subsection{Pembahasan}

Pemahaman konsep yaitu salah satu tujuan penting dalam pembelajaran matematis, dengan adanya pengertian pemahaman konsep siswa dapat mengerti, menafsirkan, menerjemahkan atau menyatakan sesuatu dengan cara sendiri tentang materi yang dipelajarinya. Pemahaman konsep sangat penting, karena dengan menguasai konsep akan memudahkan siswa dalam belajar matematika. Ketidakmampuan siswa dalam memahami konsep-konsep matematika akan mengakibatkan masalah yang luas dalam mempelajari konsep matematika secara umum.

Ketika siswa memahami konsep matematika dengan baik dalam artian siswa tidak sekedar mengetahui atau mengingat sejumlah konsep yang dipelajarinya, tetapi mampu mengungkapkan kembali dalam bentuk lain baik dari suatu kalimat seharihari kemudian dituliskan kedalam bentuk simbol matematis maupun sebaliknya, karena pemahaman konsep matematis, siswa tidak hanya menghapal saja akan tetapi siswa mampu memprediksi kelanjutan dari suatu konsep sehingga mereka bisa menghadapi permasalahan yang bisa dihadapi.

Hasil tes pemahaman konsep matematika dapat dijadikan acuan untuk melihat sejauh mana siswa dalam memperoleh pembelajaran matematika dan mengembangkan pemikirannya dari apa yang didapatkan dalam proses pembelajaran matematika. Untuk mengetahui hasil tes siswa maka perlu dilakukan suatu penilaian. Dalam penelitian ini penilaiannya mengacu pada indikator pemahaman konsep meliputi empat kriteria, yaitu menyajikan konsep dalam berbagai bentuk representasi matematis, menyatakan ulang sebuah konsep, mengklasifikasikan objek-objek menurut sifat-sifat tertentu (sesuai dengan konsepnya), mengaplikasikan konsep atau algoritma pemecahan masalah.

Diperoleh gambaran secara umum untuk 25 orang siswa tentang pemahaman konsep matematika pada materi operasi bilangan bulat. Dari hasil sebelumnya didapat bahwa kemampuan pemahaman konsep matematika dari 25 orang siswa ada 19 orang siswa dengan persentasi $76 \%$ berada dalam ketegori sedang. Ini artinya pemahaman konsep matematika dari peserta didik itu tergolong sedang. Hal ini dibenarkan dan didukung dengan hasil dari 4 indikator dimana dari hasil penilaian perindikator tersebut semua indikator dalam kategori sedang. Sehingga dapat disimpulkan bahwa pemahaman konsep matematika pada materi operasi bilangan bulat dikelas VII SMP Negeri 4 Gorontalo tergolong sedang.

\section{Kesimpulan}

Hasil analisis menujukan bahwa pemahaman konsep matematika pada materi operasi bilangan bulat tergolong sedang. Dari 25 siswa terdapat 19 peserta didik dengan persentasi $76 \%$ berada pada kategori predikat sedang. Hal ini dibenarkan dan didukung dengan hasil perindikator dimana dengan uraian hasil penilaian perindikator terdapat semua indikator dalam kategori predikat sedang Sehingga dapat disimpulkan bahwa pemahaman konsep matematika pada materi operasi bilangan bulat dikelas VII SMP Negeri 4 Gorontalo tergolong sedang.

\section{Referensi}

[1] H. B. Uno, Perencanaan Pebelajaran, Jakarta: PT. Bumi Aksara, 2011.

[2] H. B. Uno, and kuadrat, Mengelola Kecerdasan Dalam pembelajaran, Jakarta: PT. 
Bumi Aksara, 2009.

[3] Masitoh and Prabawanto, "Peningkatan Pemahaman Konsep Matematikas Siswa SMP Dalam Pembelajaran Menggunakan Model Penemuan Terbimbing (Discovery Learning)," Edu-Mat Jurnal Pendidikan Matematika., Vol. 4, no. 1, pp. 18-19, 2016.

[4] S. Paputungan, " Pengaruh Pembelajaran Model Kooperatif Tipe Team-Dame Tournament Terhadap Pemahaman Konsep Matematiak Siswa Pada Materi Persamaan dan Pertidaksamaan Linear Satu Variabel Kelas VII di SMP Negeri 1 Batudaa," Universitas Negeri Gorontalo, 2015.

[5] B. Febriyanto, dkk, "Meningkatkan Pemahaman Konsep Matematis Dalam Penggunaan Median Kantong Bergambar Pada Materi Perkalian Bilangan Dikelas II Sekolah Dasar," Jurnal Cakrawala Pendas., Vol. 4, no. 2, pp. 25-29, 2018.

[6] A. A. Jeheman, B. Gunur, and S. Jelatu, "Pengaruh Pendekatan Matematika Realistik Terhadap Pemahaman Konsep Matematika Siswa," Jurnal Pendidikan Matematika., Vol. 8, no. 2, pp. 191-202, 2019.

[7] N. Yulianty, "Kemampuan Pemahaman Konsep matematika Siswa dengan Pendekatan Pembelajarana matematiak Realistik," Jurnal Pendidikan Matematika Raflesia., Vol. 4, no. 1, pp. 60-65, 2019.

[8] A. G. Fahrudin, E. Zuliana, H. S. Bintoro, "Peningkatan Pemahaman Konsep Matematika Melalui Realistik Mathematic Berbaru Alat Peraga Bongpas," Jurnal Ilmiah Pendidikan Matematika., Vol. 1, no. 1, pp. 14-20, 2018.

[9] M. Amri, "Pengembangan Bahan Ajar Elektronik Berbasis Geogebra Dengan Model Penemuan Terbimbing Pada Materi Bilanagan Bulat," in Prosiding Seminar Nasional Matematika, 2018, pp. 792-795.

[10] N. Nurhairunnisah and S. Sujarwo, "Bahan Ajar Interaktif Untuk Meningkatkan Pemahaman Konsep Matematika Pada Siswa SMA Kelas X," Jurnal inovasi teknoligi Pendidikan., Vol. 5, no. 2, pp. 192-203 , 2018.

[11] U. Rosyidah, dkk, "Analisis Pemahaman Konsep matematika Mahasiswa Progran Studi Pendidikan Matematika Dalam Mata Kuliah Aljabar Dasar," Jounal Of Mathematics Education., Vol. 1, no. 1, pp. 57-67, 2020.

[12] K. A. Y. Pauweni, K. Usman, and A. W. Abdullah, "Deskripsi Pemahaman Konsep Matematika pada Materi Bangun Ruang Sisi Lengkung," Euler J. Ilm. Mat. Sains dan Teknol., vol. 7, no. 2, pp. 37-44, 2019.

[13] B. P. Khairani, M. Maimunah, and Y. Roza, "Analisis Kemampuan Pemahaman Konsep Matematis Siswa Kelas XI SMA/MA Pada Materi Barisan Dan Deret," J. Cendekia J. Pendidik. Mat., vol. 5, no. 2, pp. 1578-1587, 2021, doi: https://doi.org/10.31004/cendekia.v5i2.623.

[14] B. P. Khairani, M. Maimunah, and Y. Roza, "Analisis Kemampuan Pemahaman Konsep Matematis Siswa Kelas XI SMA/MA Pada Materi Barisan Dan Deret," J. Cendekia J. Pendidik. Mat., vol. 5, no. 2, pp. 1578-1587, 2021, doi: https:// doi.org/10.31004/cendekia.v5i2.623.

[15] B. P. Khairani, M. Maimunah, and Y. Roza, "Analisis Kemampuan Pemahaman Konsep Matematis Siswa Kelas XI SMA/MA Pada Materi Barisan Dan Deret," J. 
N. C. Yanala, dkk | Analisis Pemahaman Konsep matematika ...

Cendekia J. Pendidik. Mat., vol. 5, no. 2, pp. 1578-1587, 2021, doi: https:// doi.org/10.31004/cendekia.v5i2.623.

[16] S. Arikunto, Prosedur Penelitian Suatu Pendekatan Praktik, Jakarta : PT. Rineka Cipta, 2008.

[17] T. Machmud, "peningkatan Kemampuan Pemecahan Masalah Matematis dan Self-Efficacy Siswa SMP Melalui Pendekatan Problem-Centered Dengan Strategi Scaffolding," Universitas Pendidikan Indonesia, 2013. 